\title{
The Tagliamento River A model ecosystem of European importance
}

\section{Journal Article}

\section{Author(s):}

Tockner, Klement; Ward, James V.; Arscott, David B.; Edwards, Peter J.; Kollmann, Johannes; Gurnell, Angela M.; Petts, Geoffrey E.; Maiolini, Bruno

\section{Publication date:}

2003-09

\section{Permanent link:}

https://doi.org/10.3929/ethz-b-000053607

\section{Rights / license:}

In Copyright - Non-Commercial Use Permitted

\section{Originally published in:}

Aquatic Sciences 65(3), https://doi.org/10.1007/s00027-003-0699-9 


\title{
Overview Article
}

\section{The Tagliamento River: A model ecosystem of European importance}

\author{
Klement Tockner $^{1, *}$, James V. Ward ${ }^{1}$, David B. Arscott ${ }^{1}$, Peter J. Edwards ${ }^{2}$, Johannes Kollmann ${ }^{3}$, \\ Angela M. Gurnell ${ }^{4}$, Geoffrey E. Petts ${ }^{5}$ and Bruno Maiolini ${ }^{6}$ \\ 1 Department of Limnology, EAWAG/ETH, Überlandstr. 133, CH-8600 Dübendorf, Switzerland \\ 2 Geobotanical Institute, ETH, CH-8044 Zürich, Switzerland \\ 3 Department of Ecology, Royal Veterinary and Agricultural University, Copenhagen, Denmark \\ ${ }^{4}$ School of Geography, University of Birmingham, Birmingham B15 2TT, U.K. \\ ${ }^{5}$ King's College, London, U.K. \\ ${ }^{6}$ Museo Tridentino di Scienze Naturali, I-38100 Trento, Italy
}

Received: 21 May 2003; revised manuscript accepted: 21 July 2003

\begin{abstract}
In NE Italy is a remarkable floodplain river that retains the dynamic nature and morphological complexity that must have characterized most Alpine rivers in the pristine stage. This river system, the Fiume Tagliamento, constitutes an invaluable resource not only as a reference site for the Alps, but as a model ecosystem for large European rivers. The Tagliamento has a number of attributes that have not been given due consideration in river ecology: (i) an immense corridor of more than 150 $\mathrm{km}^{2}$ that connects the land and the sea and two biomes,

the Alps and the Mediterranean; (ii) unconstrained floodplain segments characterised by a dynamic mosaic of aquatic/terrestrial habitats; and (iii) a large number of vegetated islands (ca. 700). We believe it is critical to understand the functional roles of these endangered attributes in order to effectively engage in river conservation and management programmes. The Tagliamento River in Italy offers the rare opportunity to investigate natural processes at a scale that can be studied almost nowhere else in Europe.
\end{abstract}

Key words. Floodplain; restoration; conservation; landscape; biodiversity; flow pulse; flood pulse; reference ecosystem.

\section{Introduction}

Gravel-bed rivers are characterised by their dynamic nature, by alluvial deposits containing groundwater aquifers, and by geomorphic features that include extensive flood plains (Billi et al., 1992 ). Braided gravel-bed rivers are widespread in temperate piedmont and mountain-valley environments. Today, in much of the world, however, gravel-bed rivers bear little resemblance to their highly dynamic natural state (Tockner and Stanford, 2002). The primary features that characterise gravel-bed

* Corresponding author phone: +41 18235616 or 51 72; fax: +41182353 15; e-mail: tockner@eawag.ch Published on Web: September 23, 2003 rivers are often the ones most strongly influenced by human intervention. In Europe, for example, almost all large Alpine rivers were "trained" during the first half of the $20^{\text {th }}$ century, in many cases over 100 years ago (Petts et al., 1989; Dynesius and Nilsson, 1994; Plachter, 1998). The remaining natural and semi-natural remnants, less than $10 \%$ of the total river length, are primarily located in the uppermost headwaters (Martinet and Dubost, 1992; CIPRA, 1998). A recent survey of all Austrian rivers with a catchment area of $>500 \mathrm{~km}^{2}$ showed that formerly braided and meandering sections have been particularly affected by regulation (Muhar et al., 1998). At present, $25 \%$ of confined river sections, but only $1 \%$ of braided and meandering sections, remain intact. 
In NE Italy there is a remarkable gravel-bed river that retains the dynamic nature and morphological complexity that must have characterised many Alpine rivers in the pristine stage. This river system, the Fiume Tagliamento, is considered as the last morphologically intact river in the Alps (Lippert et al., 1995; Müller, 1995; Ward et al., $1999 \mathrm{~b}$ ) and, therefore constitutes an invaluable resource, not only as a reference ecosystem for the Alps but also as a model ecosystem for large temperate rivers. The Tagliamento has a number of attributes that have not been given due consideration in river ecology: (i) an immense corridor of more than $150 \mathrm{~km}^{2}$ that connects the land and the sea and two biomes, the Alps and the Mediterranean (Ward et al., 1999b); (ii) unconstrained floodplain segments characterised by a dynamic mosaic of aquatic/terrestrial habitats (Tockner and Ward, 1999; Gurnell et al., 2000a, b; Van der Nat et al., 2002; Arscott et al., 2002); and (iii) a large number of vegetated islands (Edwards et al., 1999; Kollmann et al., 1999; Ward et al., 2000; Gurnell et al., 2001). We believe it is critical to understand the functional roles of these endangered attributes in order to effectively engage in river conservation and management programmes.

The following text begins with a general description of the environmental setting of the region. This is followed by information of the Tagliamento catchment, including hydrological conditions and human impacts. The remaining of the text focuses on the river corridor specifically, including geomorphic features, physico-chemical conditions, and the longitudinal distribution of plants, terrestrial invertebrates and fishes. The formation, distribution, and potential role of islands are treated in some detail.

\section{Environmental setting}

The 'Fiume Tagliamento' is the dominant river system of the Friuli region in northeastern Italy (Cattaneo et al., 1995; Fig. 1). From north to south (a linear distance of $<100 \mathrm{~km}$ ), the Tagliamento traverses four major regions: (i) the Julian and Carnian Alps, (ii) prealps, (iii) the upper and lower Friulian plain, and (iv) the coast. This steep environmental gradient from north to south is associated with climatic differences; e.g., annual precipitation ranges from 3,100 to $1,000 \mathrm{~mm}$ per year and mean annual temperature from 5 to $14^{\circ} \mathrm{C}$ (Baumgartner et al., 1983; Poldini, 1991; Fig. 1). The southern fringe of the Carnian and Julian Alps frequently receives very intensive rainstorms, resulting in severe erosion, especially in the alpine area. Torrential rainfalls, steep slopes, and extensive sediment sources generate high floods and massive sediment transport rates. The frequent reworking of the valley floor by floods constrains human habitation within the river corridor.

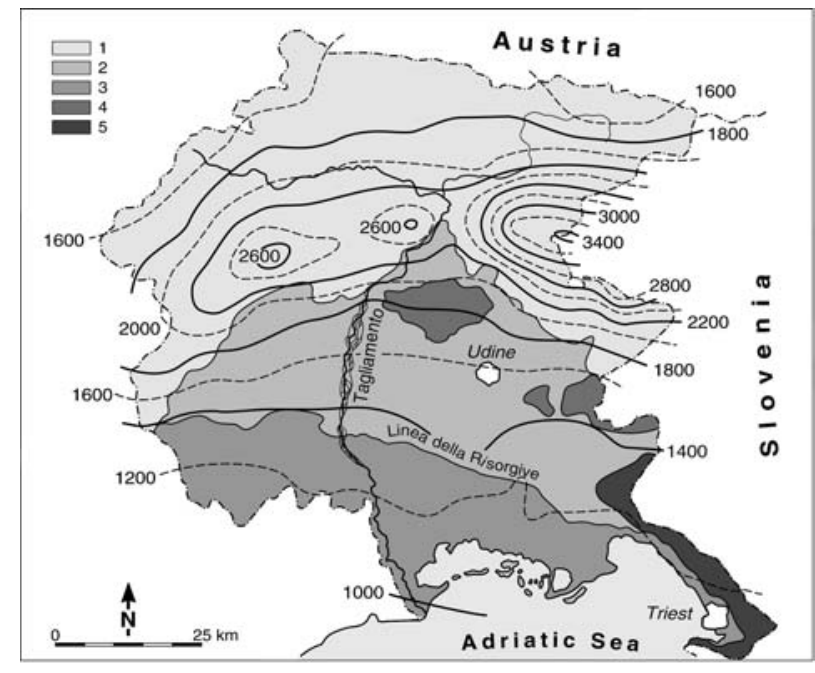

Figure 1. Climatic setting of the Tagliamento catchment within the region of Friuli-Venezia Giulia, Italy. Average annual precipitation (1951-1970) is given by isohyets in mm. 1: Alps and prealps; 2: Upper Friulian plain; 3: Glacial moraines; 4: Lower Friulian plain; 5: Karstic area (Based on Regione Autonoma Friuli-Venezia Giulia, 1982).

\section{Geology and glacial history}

The alpine area of Friuli mainly consists of limestone, with a spatial sequence of Silurian, Devonian, Triassic, Jurassic and Cretaceous formations north to south (Astori, 1993; Martinis, 1993). A precise delineation of the watershed of the Tagliamento is almost impossible due to the high complexity of groundwater drainage through the limestone karst. Limestone is occasionally intermixed with layers of gypsum that lead to high sulphate concentrations in the Tagliamento (Arscott et al., 2000). The catchment is tectonically active, continuously developing faults and overthrusts. Many tributary streams, like the Fella, have sharp bends following the direction of these faults (Fig. 2).

The prealpine mountains mainly consist of limestone (Jurassic-Cenozoic) and Flysch s.s. (calcareous flysch, molasse). The Friulian plain consists primarily of Tertiary and Quaternary sediments. The upper plain consists of a vast alluvial aquifer several hundred meters deep, and is composed of fluvioglacial sediments of high permeability (Ward et al., 1999b). To the south the aquifer sediments are intermixed with layers of marine deposits (sand and clay), which reduce permeability and result in upwelling of ground water ('Linea delle risorgive', see: Fig. 1).

The lowest glaciers of the Eastern Alps are located in the Julian Alps on the northern slopes of Mt. Canin (2587 $\mathrm{m}$ a.s.1.), with the termini of the glaciers at altitudes $<2000 \mathrm{~m}$ a.s.1. Within the last decades, however, the glaciated area has decreased from about $10 \mathrm{~km}^{2}$ to $3 \mathrm{~km}^{2}$ (Mosetti, 1983). Harsh environmental conditions also are 


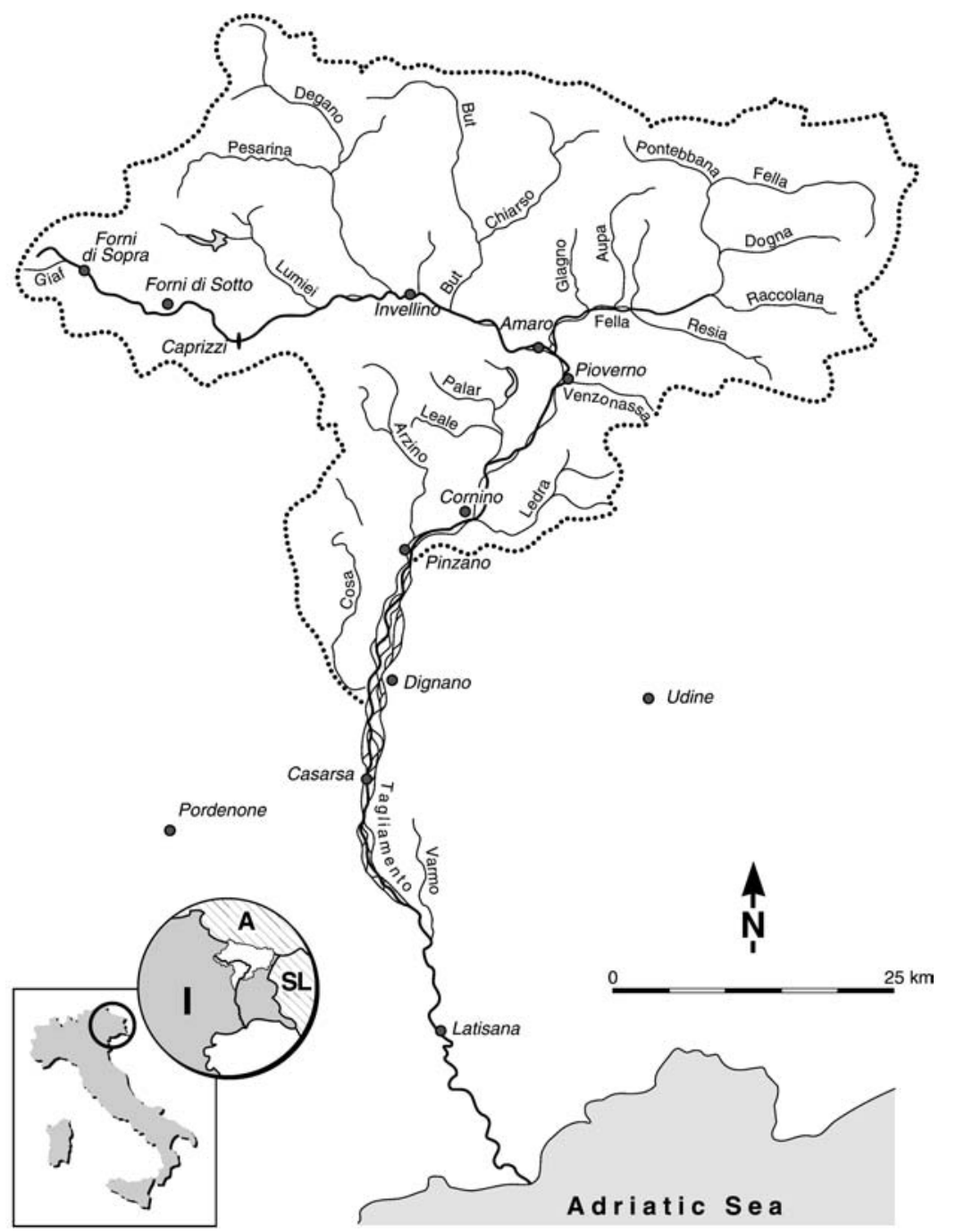

Figure 2. Catchment map of the Tagliamento, with major tributaries and towns. Inset shows the location of the river in Italy (I), near the borders of Austria (A) and Slovenia (SL) (modified after Ward et al., 1999b).

reflected by the position of the tree line at about $1500 \mathrm{~m}$ a.s.1., 300-500 m lower than in the central Alps (Gentilli, 1971).

\section{Phytogeography}

The steep environmental gradient from the Alpine region towards the Adriatic Sea is reflected in floristic distribution patterns. Arctic-alpine species dominate the upper catchment, some of which (e.g., Adenostyles glabra, Alnus viridis, Arabis alpina or Soldanella alpina) have never been found in the middle or lower reaches of the Tagliamento (Poldini, 1991; nomenclature follows Tutin et al., 1964-1980). Some arctic-alpine species are geographically limited either by poor dispersal of seeds (e.g., Valeriana saxatilis) or by specific habitat requirements (e.g., Trollius europeus). In contrast, the (sub)mediterranean species mainly occur in lower sections of the
Tagliamento catchment (e.g., Cucubalus baccifer, Orchis laxiflora, Platanus hybrida and Populus alba). These species are most prominent in SE Friuli, but have never reached the upper catchment of the Tagliamento.

Overall, there are marked differences in floral richness along the Tagliamento (Poldini, 1991). In the Upper Tagliamento valley, the number of vascular species (based on $11 \times 13 \mathrm{~km}^{2}$ plots) is between 500 and 800 . The highest species richness (1100-1200 species per plot) was found between Amaro and Cornino (for location see Fig. 2) where the river leaves the Alps; this is mainly a consequence of the co-occurrence of Alpine and lowland species. Additionally, the number of endemic species is rather high in this part of the catchment (5-12 spp. per plot). Further downstream, the species number decreases from the Alpine foothills (700-900) towards the Adriatic Sea $(300-500)$. 
Table 1. Number, total and average lengths $(\mathrm{km})$ of stream segments of each stream order (Strahler order system) in the Tagliamento catchment (based on the analysis of information derived from a map produced by Carta Idrographica, 1994).

\begin{tabular}{lccc}
\hline Stream order & $\begin{array}{c}\text { Number of } \\
\text { stream segments }\end{array}$ & $\begin{array}{c}\text { Total stream } \\
\text { segment length }(\mathrm{km})\end{array}$ & $\begin{array}{c}\text { Average length of } \\
\text { stream segment }(\mathrm{km})\end{array}$ \\
\hline 1 & 1,663 & 1,405 & 0.84 \\
2 & 416 & 631 & 1.52 \\
3 & 90 & 320 & 3.56 \\
4 & 21 & 155 & 7.38 \\
5 & 6 & 85 & 8.00 \\
6 & 2 & 16 & 114.00 \\
7 & 1 & 114 & - \\
\hline
\end{tabular}

\section{Catchment description}

The Tagliamento is a 7 th order river $\left(46^{\circ} \mathrm{N}, 12^{\circ} 30^{\prime} \mathrm{E}\right.$; Fig. 2) that flows unimpeded by high dams for $172 \mathrm{~km}$ to the Adriatic Sea. The Tagliamento drains an approximately $2580 \mathrm{~km}^{2}$ area. It is a mountainous river with more than $70 \%$ of the catchment located in the Alpine area. The highest peak in the catchment is Mt. Coglians $(2781 \mathrm{~m}$ a.s.1.). The mean altitude of the catchment is $987 \mathrm{~m}$ a.s.l. Areas above $1000 \mathrm{~m}$ a.s.1. (ca. $50 \%$ of the Tagliamento catchment), are practically uninhabited (Steinicke, 1991).

The total stream network length for the entire catchment is $2726 \mathrm{~km}$, corresponding to an average stream density of $0.85 \mathrm{~km} \mathrm{~km}^{-2}$ (Table 1). First and second order stream segments account for $75 \%$ of total length and $95 \%$ of all stream segments, respectively. Most of these low order segments are intermittent and dry at the surface during low flow periods in winter and summer (Hormann, 1964).

\section{Hydrology}

The Tagliamento is characterised by a flashy pluvio-nival flow regime (Fig. 3 a), with an average discharge of ca. 90 $\mathrm{m}^{3} \mathrm{~s}^{-1}$ at Pioverno. The 2, 5 and 10 year floods are estimated to be 1100, 1600 and $2150 \mathrm{~m}^{3} \mathrm{~s}^{-1}$ (Maione and Machne, 1982). Mosetti (1983) calculated an average total annual discharge (1929-1939) of $3.83 \mathrm{~km}^{3}$ at Pioverno (range: $2.64-5.18 \mathrm{~km}^{3}$, catchment area: $1900 \mathrm{~km}^{2}$ ), and $4.72 \mathrm{~km}^{3}$ at Pinzano $\left(2300 \mathrm{~km}^{2}\right)$. As described above, the Tagliamento is influenced by both Alpine and Mediterranean snowmelt and precipitation regimes. As a result, it exhibits a bimodal flow pattern with peaks in spring and autumn (Fig. 3 B).

In unconfined floodplain sections, maximum annual amplitudes of surface water levels are about $2 \mathrm{~m}$ (Fig. $3 \mathrm{~A}$ ). Even small fluctuations in discharge, however, lead to marked areal expansions and contractions of surface waters, a characteristic of many alluvial rivers (Tockner et al., 2000; Van der Nat et al. 2002). In the artificiallyconstrained section downstream of Latisana, however, water level fluctuations of $\geq 7 \mathrm{~m}$ occur.
Downstream of Pinzano, the Tagliamento loses a large percentage of its surface flow by infiltration through a vast alluvial aquifer dominated by highly permeable gravel (average porosity 10\%). Under low flow conditions, the river here lacks surface flow (maximum dry length: $20 \mathrm{~km}$ ). This is a natural feature of Mediterranean rivers that has been exacerbated by water abstraction. In this section water drains into the alluvial aquifer through the river bed (on average $\sim 3 \mathrm{~m}^{3} \mathrm{~s}^{-1}$ per river $\mathrm{km}$; D. Schlaepfer and A. Rotach, pers. comm.) and, although some of this water returns to the river in its downstream sections $\left(\sim 0.3 \mathrm{~m}^{3} \mathrm{~s}^{-1}\right.$ per river $\left.\mathrm{km}\right)$, much is lost to adjacent catchments. For example, the Fiume Stella located to the east of the Tagliamento receives a major portion of its
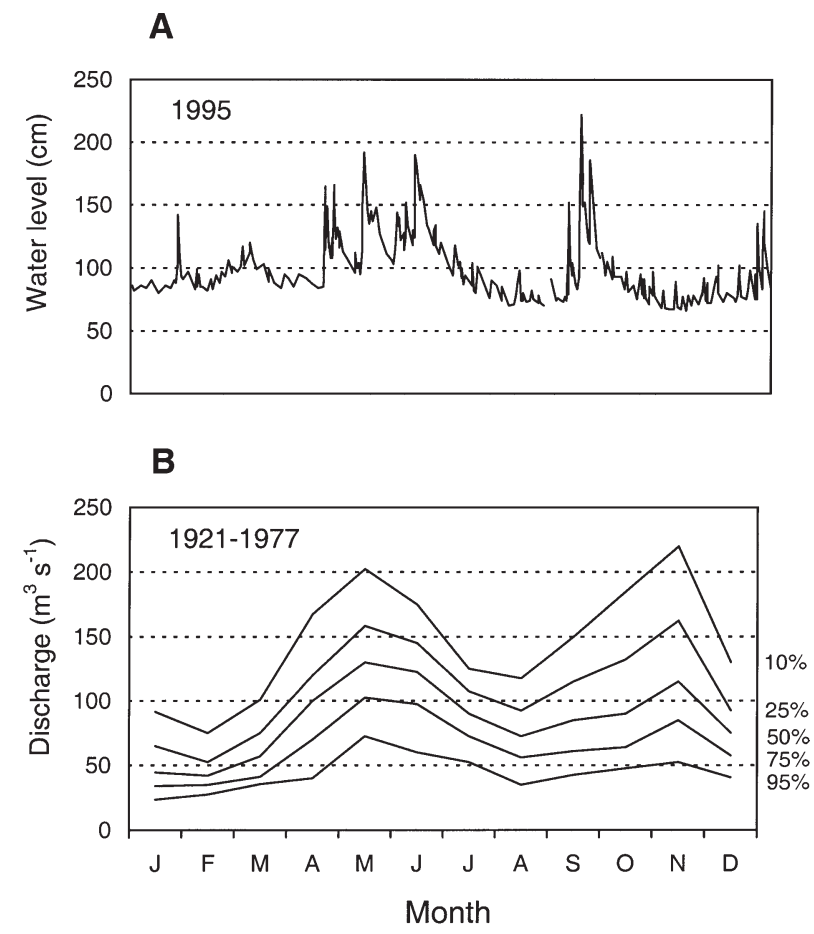

Figure 3. A: Hydrograph of the Tagliamento in 1995 (at Pinzano). B: Seasonal flow patterns (probability curves, in \%, for 1921-1977; Electroconsult, 1979). 
discharge from Tagliamento water draining through the alluvial aquifer (Ward et al., 1999b).

\section{Human impacts}

Although the Tagliamento is considered to be the most natural river system in the Alps, it is not without human impacts. Major human influences on the main river corridor are (i) water abstraction in the upper Tagliamento valley, (ii) organic pollution, and (iii) gravel exploitation. Many small tributaries contain drop structures to inhibit erosion and channel incision (Stefanini, 1982). Water is abstracted for hydropower generation in the upper area, altering the flow regimes of the Degano, the Lumiei, and sections of the main stem Tagliamento (Table 2). Downstream of the weir at Caprizzi (for location see Fig. 2), the Tagliamento frequently loses surface flow over a distance of $25 \mathrm{~km}$. Additionally, a maximum of $23 \mathrm{~m}^{3} \mathrm{~s}^{-1}$ is abstracted for irrigation purposes at Ospedaletto south of Pioverno (Canale Ledra). Nevertheless, large tributaries like the Fella, But and Arzino are characterised by a natural flow regime. In addition, the flood dynamics of the main stem of the Tagliamento is largely unaffected by water abstraction. The Tagliamento suffers from organic pollution between Tolmezzo and its confluence with the Fella, and in the chanalised section downstream of Latisana; however, water quality has improved considerably in recent years (Provincia di Udine, 1997). There are lateral dams along some sections (e.g. between Pioverno and Pinzano; and downstream of Dignano). However, they are far outside the active corridor and primarily used to protect agricultural land.

\section{The corridor}

The river corridor, which is morphologically intact along virtually its entire length, is the feature that makes the Tagliamento unique in the Alps. The corridor has escaped massive river engineering and floodplain development

Table 2. Mean flow (MQ, $\mathrm{m}^{3} \mathrm{~s}^{-1}$ ), diverted flow, and residual flow in the Tagliamento and in major tributaries (L. Tonus, pers. comm.).

\begin{tabular}{lccc}
\hline & $\begin{array}{c}\text { MQ } \\
\left(\mathrm{m}^{3} \mathrm{~s}^{-1}\right)\end{array}$ & $\begin{array}{r}\text { Diverted Q } \\
\left(\mathrm{m}^{3} \mathrm{~s}^{-1}\right)\end{array}$ & $\begin{array}{r}\text { Residual Q } \\
\left(\mathrm{m}^{3} \mathrm{~s}^{-1}\right)\end{array}$ \\
\hline Tagliamento (Forni di Sopra) & 1.8 & 1.2 & 0.6 \\
Tagliamento (Forni di Sotto) & 5.4 & 1.7 & 3.7 \\
Tagliamento (Caprizzi) & 9.6 & 8.0 & 1.6 \\
Lumiei & 2.9 & 2.9 & 0.0 \\
Degano & 12.1 & 10.0 & 2.1 \\
Tagliamento (Invillino) & 25.6 & 21.1 & 4.5 \\
But & 16.3 & 0.0 & 16.3 \\
Fella & 37.6 & 0.0 & 37.6 \\
Tagliamento (Pioverno) & 87.3 & 21.1 & 66.2 \\
\hline
\end{tabular}

schemes, thus retaining the functional characteristics of a near-pristine system: strong longitudinal, lateral and vertical connectivity, high habitat heterogeneity, and a characteristic sequence of geomorphic types.

\section{Geomorphological diversity}

The riparian corridor consists of five major landscape elements: surface water, bare gravel, vegetated islands, riparian forest and topographical low areas that are unforested (Table 3). The first three landscape elements form the active corridor with a total area of $61.7 \mathrm{~km}^{2}$. The river retains an intact riparian margin, with a total area of $32 \mathrm{~km}^{2}$, throughout almost its entire length. Considerable parts of topographically low areas, adjacent to the meandering and regulated sections in particular, are under other land uses, primarily agriculture. These lowland areas tend to be situated on the more stable terraces along the edges of the corridor, although they are partly inundated during major floods. In summary, the riparian corridor of the Tagliamento is about $150 \mathrm{~km}^{2}$ (excluding tributary corridors), comparable in size to some of Europe's national parks such as the Alluvial Zone National Park, Austria $\left(93 \mathrm{~km}^{2}\right)$, the Swiss National Park $\left(169 \mathrm{~km}^{2}\right)$, and the National Park "Neusiedlersee", Austria, $\left(200 \mathrm{~km}^{2}\right)$.

The active zone of the Tagliamento reaches a maximum width of about $2 \mathrm{~km}$ in the upper part of the coastal plain section (Fig. 5). In some reaches the river divides into more than 10 channels with a maximum shoreline length of $22 \mathrm{~km} \cdot \mathrm{km}^{-1}$ and a total shoreline length along the entire river corridor of $940 \mathrm{~km}$ at around mean water level (based on an analysis of 1:10,000 scale maps). Shoreline length influences species diversity and species density of both aquatic and terrestrial communities. In the Tagliamento, Reich (1994) found a positive relationship

Table 3. The river corridor of the Tagliamento: Summary statistiics (modified after Ward et al., 1999a, b; Gurnell et al., 2000a).

\begin{tabular}{lr}
\hline Active corridor area & $61.7 \mathrm{~km}^{2}$ \\
Gravel area (excl. water) & $38.7 \mathrm{~km}^{2}$ \\
Island area & $10.6 \mathrm{~km}^{2}$ \\
Water area & $12.4 \mathrm{~km}^{2}$ \\
Riparian forest area & $32.0 \mathrm{~km}^{2}$ \\
Riparian corridor area $^{2}$ & $\geq 150 \mathrm{~km}^{2}$ \\
Number of gravel bars $_{\text {Number of islands }}^{3}$ & 950 \\
Length of riparian ecotone $^{4}$ & 652 \\
Length of shoreline & $670 \mathrm{~km}$ \\
\hline
\end{tabular}

${ }^{1}$ Marginal band of riparian woodland which is periodically reworked by lateral displacement of the active zone (Gurnell et al., 2000a).

${ }^{2}$ The riparian corridor includes the active zone, the riparian forest area, and the topographically low area on either side of the river (to a maximum of $2 \mathrm{~km}$ )

${ }^{3}$ Vegetated islands of $>0.01$ ha.

${ }^{4}$ Including the perimeter of islands and the riparian zone along the lateral flood plain (Ward et al., 1999b). 


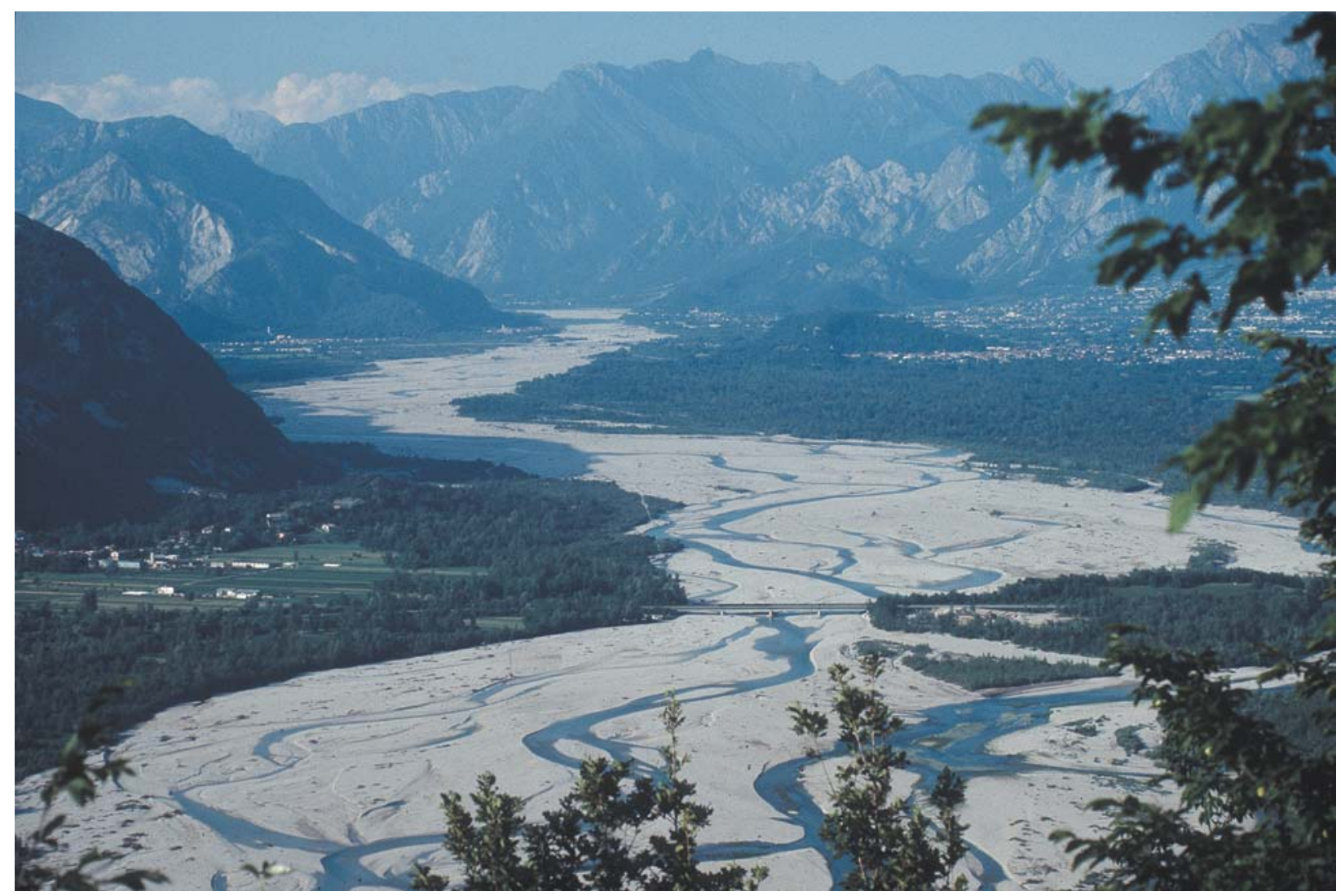

Figure 4. The Tagliamento after leaving the Alps near Gemona (Photo: K. Tockner)

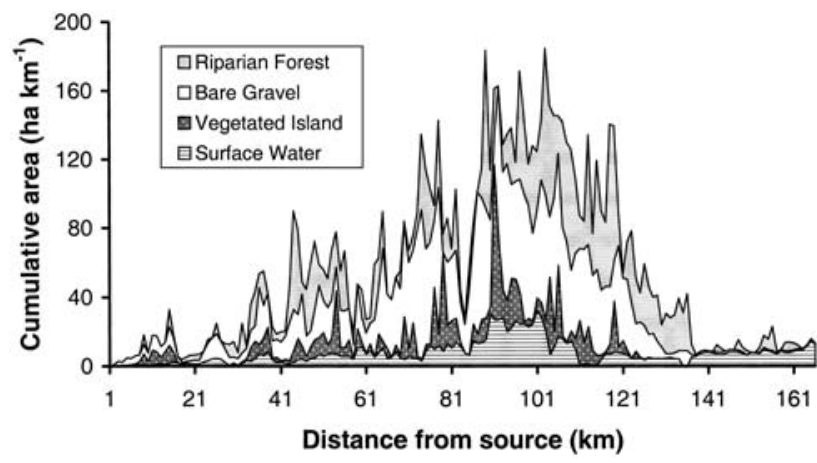

Figure 5. Distribution of four major landscape elements along the river corridor (based on the analysis of information derived from 1:10000 scale maps, 1984-1985) (Gurnell et al., 2000a).

between shoreline length and the number of breeding pairs of Charadrius dubius (Little Ringed Plover), with up to 22 breeding pairs per river-km. Along the Danube River (Austria), Wintersberger (1996) demonstrated that species diversity of $0+$ fish was significantly related to shoreline length.

The complex downstream variability in river discharge and sediment transport regimes, the local hydraulic conditions, and the materials within which the channel is formed have resulted in a high diversity of ge-

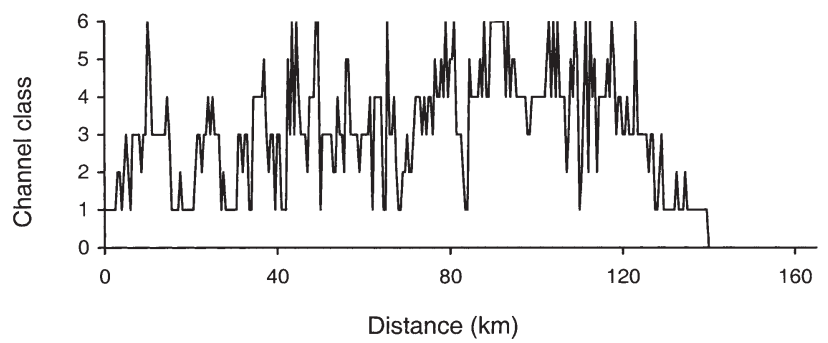

Figure 6. Variations in river channel geomorphological style along the Fiume Tagliamento. $0=$ channelised; $1=$ single thread; $2=$ single thread with backwaters; 3 = braided; $4=$ braided with occasional islands; $5=$ island braided; $6=$ highly island braided (based on the analysis of information derived from 1:10000 scale maps; 1984-1985).

omorphological styles of river planform along the river corridor. Figure 6 illustrates that at least six geomorphological styles are present, ranging from single threads to a variety of multiple thread patterns. A particular characteristic of the Tagliamento is the large number of islands. In some reaches (Fig. 5, class 6 in Fig. 6) more than 50\% of the area of the active zone is covered by vegetated islands. Another important point is that the full complexity of channel planform is not fully represented in Figure 6 because there is considerable variety within the single 
thread category. Whereas single thread sections in the headwaters have a low sinuosity as a result of their confinement within narrow valleys and gorges, the short single thread sections within the central sections are less confined and are, therefore, able to develop a slightly higher sinuosity within the river corridor. The single thread unconfined section in the downstream part of the coastal plain section has a highly sinuous, meandering course within this low gradient, unconfined, relatively fine sediment environment.

\section{Flow and flood pulses}

Flooding represents the major physical disturbance along river corridors (flood pulses sensu Junk et al., 1989). Rivers also experience frequent but smaller water level fluctuations ("flow pulses" sensu Tockner et al., 2000) that occur well below bankfull discharge. Although not responsible for rapid morphological restructuring, these flow pulses are important for creating and maintaining habitat heterogeneity and for ecosystem processes (Benke et al., 2000; Arscott et al., 2002; Van der Nat et al., 2002).

Along the Tagliamento corridor, aquatic habitat change caused by flooding was investigated in five different reaches, ranging from near the headwaters to near the mouth (Arscott et al., 2002). The highest degree $(62 \%)$ of aquatic habitat turnover occured in a braided headwater section. The degree of habitat turnover decreased with decreasing elevation to $\sim 20 \%$ in the meandering reach close to the mouth. In contrast to turnover rate, braiding, sinuosity, and aquatic habitat composition changed little in response to flooding. Floods changed the configuration of floodplain habitats, whereas habitat composition and heterogeneity remained relatively stable. These results support the applicability of the shifting mosaic steady-state model to riverine flood plains (Bormann and Likens, 1979). These results also highlight the importance of floods in maintaining habitat diversity in dynamic flood plains.

We investigated inundation processes in a bar- and an island-braided flood plain (Van der Nat et al., 2002). Despite complex inundation patterns, a linear relation between water level and the arcsine square root of inundated area existed in both reaches. A second-order polynomial relation existed between water level and shoreline length. Using these relations as simple predictive models, we converted several years of water level data into predictions for degree of inundation and shoreline length. Simulated degree of inundation strongly resembled the hydrograph. Complete inundation of the active flood plain occured 3-4 times per year; however, the degree of inundation was highly dynamic during most of the year. Simulated shoreline length averaged $171 \mathrm{~m} \mathrm{ha}^{-1}(12.8 \mathrm{~km}$ $\mathrm{km}^{-1}$ ) with a maximum of $197 \mathrm{~m} \mathrm{ha}^{-1}\left(14.7 \mathrm{~km} \mathrm{~km}^{-1}\right)$.
During major flood events, shoreline length decreased to $28 \mathrm{~m} \mathrm{ha}^{-1}\left(2.1 \mathrm{~km} \cdot \mathrm{km}^{-1}\right)$. A braiding index and upstream surface hydrologic connectivity were positively related to water level, whereas total area of isolated waterbodies was negatively related to water level (Van der Nat et al., 2002).

\section{Structural diversity}

Different indicators of structural diversity may provide a useful approach for identifying 'landscape filters' that operate at different scales to influence biodiversity patterns across the riverine landscape. Tockner and Ward (1999) measured four different components of structural diversity (geomorphic, hydraulic, ecotonal and substrate heterogeneity) along the entire corridor (Fig. 7). Each of these indicators exhibited different longitudinal patterns. Fine scale heterogeneity (substratum heterogeneity)
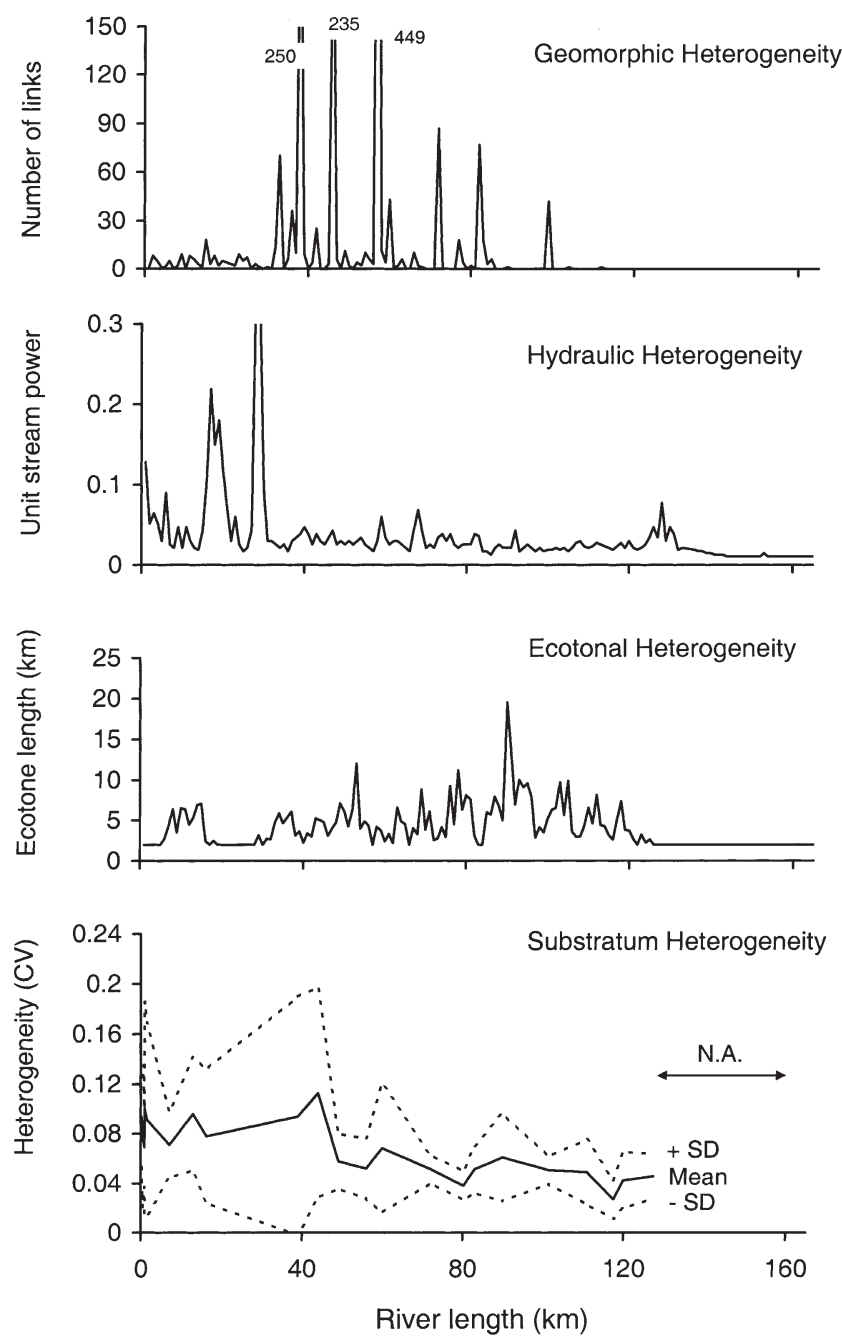

Figure 7. Four indices of structural diversity along the river corridor (modified after Tockner and Ward, 1999). N.A. = not applicable. $\mathrm{SD}=$ standard deviation. 
peaked in the headwater section and decreased with distance from the source. Ecotone riparian length peaked in the middle reaches. Stream power (hydraulic heterogeneity) was highest in steep narrow headwater channels, in reaches where the valley was constricted by rock outcrops and alluvial fans, and at transitions between geomorphologic sections (e.g., multiple to single thread channel patterns). The number of links (geomorphic heterogeneity) was highest in the middle reaches where major tributaries enter the river. In the headwaters many small tributaries joined the main stem but no tributaries enter the river downstream from river km 120 (Fig. 7). These simple scalar patterns of structural diversity may provide insight into the mechanisms responsible for hierarchical arrangement of biodiversity in river corridors (Ward, 1998; Ward et al., 1999a; Ward and Tockner, 2001).

\section{Physico-chemical characteristics}

Chemical composition of surface waters reflects the geological setting of the catchment. The Tagliamento is classified as an 'alkaline river' with a $\mathrm{pH}>7.5$, a specific conductance of $>250 \mu \mathrm{S} \mathrm{cm}^{-1}$ and a predominace of $\mathrm{Ca}^{2+}$ (about $100 \mathrm{mg} \mathrm{L}^{-1}$ upstream of the confluence with the Fella River), $\mathrm{Mg}^{2+}\left(20 \mathrm{mg} \mathrm{L}^{-1}\right)$ and $\mathrm{HCO}_{3}^{-}$(ca. $160 \mathrm{mg}$ $\mathrm{L}^{-1}$ ). Along the river, specific conductance decreased from $2000 \mu \mathrm{S} \mathrm{cm}^{-1}$ in the uppermost headwaters to about $450 \mu \mathrm{S} \mathrm{cm}^{-1}$ in the lower reaches. High specific conduc- tance mainly results from the weathering of evaporitic sediments (gypsum). Sulphate concentrations of up to $\geq$ $2000 \mathrm{mg} \mathrm{L}^{-1}$ are classified as extreme values compared to usual concentrations in perennial world rivers and streams (Meybeck, 1996). Concentrations of phosphorus and ammonium were very low along the entire river. Concentrations of nitrate $\left(\mathrm{NO}_{3}-\mathrm{N}\right)$, however, increased from upstream to downstream with peak values of over $1.6 \mathrm{mg}$ $\mathrm{L}^{-1}$. Dissolved organic carbon (DOC) concentrations were relatively constant at about $1.0 \mathrm{mg} \mathrm{L}^{-1}$. Particulate organic carbon (POC) ranged from $0.18 \mathrm{mg} \mathrm{L}^{-1}$ at low flow to $12.1 \mathrm{mg} \mathrm{L}^{-1}$ during high flow (Table 4).

\section{Longitudinal distribution and migration of plant species}

It is likely that the active flood plain of the Tagliamento serves as an important biogeographical corridor connecting the Alps with the Mediterranean zone near the Adriatic Sea. We illustrate this function with a few examples based on plant species' distribution. The phenomenon of downstream dispersal of Alpine plants ("alpine drifters" or "Alpenschwemmlinge"; Ellenberg, 1988) is well known. Bill et al. (1999) showed that the phenomenon of downstream dispersal is relevant on short distances, but probably overestimated for long distance dispersal. A clear example of "alpine drifters" is Gypsophila repens which actually follows the Tagliamento from the headwa-

Table 4. Average physico-chemical concentrations of the Fiume Tagliamento main stem at discrete locations from its source near Passo Mauria to $127.5 \mathrm{~km}$. Cond. $=$ Specific conductance, $\mathrm{NH}_{4}-\mathrm{N}=$ ammonium, $\mathrm{NO}_{3}-\mathrm{N}=$ nitrate, $\mathrm{DN}=$ dissolved nitrogen, $\mathrm{PN}=$ particulate nitrogen, $\mathrm{SRP}=$ soluble reactive phosphorous, $\mathrm{DON}=$ dissolved organic nitrogen, $\mathrm{DP}=$ dissoveld phosphorous, $\mathrm{PN}=$ particulate phosphorous, $\mathrm{DOC}$ and $\mathrm{POC}=$ dissolved and particulate organic carbon, $\mathrm{SS}=$ suspended solids, $\mathrm{AFDM}=$ ash-free dry mass, $\% \mathrm{OM}=$ relative proportion of organic matter on SS, Chl.a = Chlorphyll-a concentration. $(n=7) . n d=$ not detectable.

\begin{tabular}{|c|c|c|c|c|c|c|c|c|c|}
\hline \multirow[t]{2}{*}{ Variable } & & \multicolumn{8}{|c|}{$\mathrm{km}$} \\
\hline & & 0.0 & 0.9 & 1.5 & 13.3 & 73.7 & 80.3 & 120.0 & 127.5 \\
\hline $\mathrm{pH}$ & & 7.90 & 8.00 & 8.06 & 8.00 & 7.83 & 7.81 & 7.92 & 7.98 \\
\hline Temp & ${ }^{\circ} \mathrm{C}$ & 8.27 & 9.53 & 9.81 & 10.36 & 13.94 & 14.74 & 16.41 & 15.69 \\
\hline Cond & $\mu \mathrm{S}$ & 2010 & 1229 & 824 & 545 & 538 & 500 & 453 & 465 \\
\hline $\mathrm{NH}_{4}-\mathrm{N}$ & $\mu \mathrm{g} / 1$ & 4 & 4 & 2 & 2 & 3 & 30 & 2 & 4 \\
\hline $\mathrm{NO}_{3}-\mathrm{N}$ & $\mu \mathrm{g} / 1$ & 274 & 364 & 337 & 461 & 553 & 734 & 1041 & 1248 \\
\hline $\mathrm{DN}$ & $\mu \mathrm{g} / 1$ & 371 & 446 & 415 & 549 & 692 & 931 & 1184 & 1405 \\
\hline $\mathrm{PN}$ & $\mu \mathrm{g} / 1$ & 13 & 12 & 9 & 9 & 21 & 35 & 21 & 35 \\
\hline DON & $\mu \mathrm{g} / 1$ & 93 & 79 & 75 & 85 & 134 & 162 & 140 & 150 \\
\hline SRP & $\mu \mathrm{g} / 1$ & nd & nd & nd & nd & nd & 4 & nd & nd \\
\hline DP & $\mu \mathrm{g} / 1$ & 1 & 1 & 1 & 1 & 2 & 9 & 1 & 2 \\
\hline PP & $\mu \mathrm{g} / \mathrm{l}$ & 5 & 2 & 2 & 4 & 12 & 23 & 15 & 19 \\
\hline DOC & $\mathrm{mg} / 1$ & 1.1 & 1.0 & 0.9 & 1.1 & 0.9 & 0.8 & 0.7 & 0.9 \\
\hline TIC & $\mathrm{mg} / 1$ & 29.8 & 30.0 & 32.2 & 34.9 & 31.1 & 34.3 & 37.0 & 37.8 \\
\hline POC & $\mathrm{mg} / 1$ & 1.39 & 0.66 & 0.42 & 1.58 & 3.04 & 3.95 & 2.55 & 2.73 \\
\hline $\mathrm{SiO}_{2}$ & $\mathrm{mg} / \mathrm{l}$ & 4.64 & 3.17 & 3.18 & 2.95 & 3.16 & 3.40 & 3.64 & 4.12 \\
\hline $\mathrm{SO}_{4}$ & $\mathrm{mg} / 1$ & 979 & 545 & 347 & 171 & 168 & 126 & 94 & 101 \\
\hline SS & $\mu \mathrm{g} / 1$ & 20.07 & 9.04 & 5.13 & 18.57 & 33.77 & 65.81 & 56.71 & 59.54 \\
\hline AFDM & $\mu \mathrm{g} / 1$ & 3.43 & 2.20 & 1.88 & 2.65 & 4.43 & 5.78 & 4.70 & 5.34 \\
\hline$\% \mathrm{OM}$ & $\%$ & 16.3 & 22.55 & 30.66 & 47.22 & 26.34 & 22.72 & 36.50 & 29.52 \\
\hline Chl.a & $\mu \mathrm{g} / 1$ & 0.11 & 0.04 & 0.06 & 0.05 & 0.11 & 0.19 & 0.04 & 0.24 \\
\hline
\end{tabular}


ter sections to the lower parts close to the Adriatic Sea (Poldini, 1991). Other vascular plants illustrating this pattern include Achnatherum calamagrostis, Globularia cordifolia, Linaria alpina or Satureja montana. Numerous Alpine species drift downstream during floods.

Different patterns of migration and distribution are expected for neophytes that are rarely found in the Alpine zone (i.e., Amorpha fruticosa, Helianthus tuberosus, Oenothera biennis, Solidago gigantea and Parthenocissus quinquefolia). These species are most common in the lower parts of the catchment that are heavily used by agriculture and harbour more ruderal species. Most neophytes, however, are unable to successfully invade intact natural vegetation (Lohmeyer and Sukopp, 1992). Both the neophytes and the Alpine drifters illustrate the importance of riparian corridors for maintaining regional biodiversity (Malanson, 1993). Since most central European rivers have been heavily modified, the Tagliamento is the last braided river in the Alps where dispersal of plants along an entire corridor can still be observed.

\section{Longitudinal distribution of terrestrial invertebrates}

Terrestrial invertebrates, carabid beetles (Insecta, Coleptera) in particular, may serve as indicators of the ecological condition of riverine flood plains (e.g., Gerken et al., 1991). Along the Tagliamento corridor, Rust (1998) identified 95 species of carabids, from a total catch of 2633 individuals. Forty nine of these species (52\%) are considered as characteristic for riparian habitats and 26 species $(27 \%)$ are listed as endangered (red data list of Austria and Switzerland). From upstream to downstream a steady increase in cumulative species richness was observed. Bembidion tibiale, B. bugnione, B. conforme, $B$. fulvipes, and B. testaceum were the dominant species, representing a distinct longitudinal replacement sequence (Rust, 1998; Heidt et al., 1998). Island-braided and meandering sections contained more diverse carabid faunas than bar-braided and constrained headwater sections. Overall, the results clearly emphasised the importance of strong longitudinal and lateral connectivity gradients in creating and maintaining high biodiversity at the catchment scale.

\section{Longitudinal distribution of fish}

The Tagliamento contains a rich fish fauna. Thirty fish species (including six freshwater species indigenous to the Adriatic area and six non-native species), and two lamprey species are present (Stoch et al., 1992; Table 5). Species diversity peaked in the lower river section between Casarsa and Latisana (Fig. 2) where cold-adapted and warm-adapted species co-occurred, albeit in different floodplain water bodies. For example, cold alluvial groundwater habitats were colonised by high densities of salmonids (mainly the grayling, Thymallus thymallus), whereas isolated floodplain lakes provided habitats for characteristic lowland species such as Tinca tinca and Esox lucius. Intact river-floodplain systems exhibit high within-reach thermal heterogeneity (Ward, 1985; Stanford et al., 1996; Arscott et al., 2001), which was largely ignored in the development of classic fish zonation concepts. Downstream of Latisana, in the brackish river section, sturgeons ( $A$. naccarii and $A$. sturio) were sometimes found (Stoch et al., 1992).

\section{Riverine islands}

One of the most distinct features of the Tagliamento is the presence of a large number of bars and vegetated islands (Figs. 8, 9). Riverine islands can be defined as "landforms, elevated above and surrounded by stream-channel branches or waterways that persist sufficiently long to establish permanent vegetation" (Osterkamp, 1998) or, in a more strict sense, as "discrete areas of woody vegetation within the active alluvial plain" (Ward et al., 2000; Gurnell et al., 2001). Processes by which islands form include avulsion, channel incision, channel migration, or deposition of bed sediments on a vegetated surface or behind a channel obstruction. Island formation is a direct result of high-energy processes that redistribute large amounts of sediments; islands are classified as "high-energy landforms" (sensu Osterkamp, 1998).

\section{Island formation}

It has been proposed that the combination of a natural flood regime, a sufficient source of sediment and large woody debris (LDW), and an unconstrained channel provides optimal conditions for the formation of islands (Edwards et al., 1999; Kollmann et al., 1999; Ward et al., 2000; Gurnell et al., 2001; Gurnell and Petts, 2002). LWD, mainly uprooted trees, transported by floods may initiate the process that transforms a gravel bar into a vegetated island (Abbe and Montgomery, 1996). Many species of floodplain trees resprout vigorously if the trunk and branches come to rest where environmental conditions are suitable; most successful in this respect are Populus nigra, Salix elaeagnos, S. alba, S. purpurea and $S$. daphoides, whereas Alnus incana is apparently less capable of regeneration, and Alnus glutinosa, Fraxinus excelsior and Pinus sylvestris lack this ability. LWD also contributes to island development by accumulating sediments within which seeds germinate.

Edwards et al. (1999) and Kollmann et al. (1999) describe in detail successional processes on gravel bars, from stranded trees to pioneer islands and finally to established islands. Island vegetation in island-braided reaches of the Tagliamento is highly dynamic, eliminated 
Table 5. Distribution of fish species along the Tagliamento (data: Stoch et al., 1992). R: very rare species. E: endemic species to the Adriatic area. *: non-native species.

\begin{tabular}{|c|c|c|c|c|c|}
\hline & Species & $\begin{array}{c}\text { Upper } \\
\text { Tagliamento }\end{array}$ & $\begin{array}{c}\text { Middle } \\
\text { Tagliamento }\end{array}$ & $\begin{array}{c}\text { Lower } \\
\text { Tagliamento }\end{array}$ & $\begin{array}{c}\text { Coastal } \\
\text { Tagliamento }\end{array}$ \\
\hline $\mathbf{E}$ & $\begin{array}{l}\text { Lampetra zanandreai } \\
\text { Petramyzon marinus }\end{array}$ & & $\begin{array}{l}X \\
X\end{array}$ & $\begin{array}{l}X \\
X\end{array}$ & \\
\hline $\mathbf{R}$ & Acipenser sturio & & & & $X$ \\
\hline \multirow[t]{4}{*}{$\mathbf{E}, \mathbf{R}$} & Acipenser naccarii & & & & $\mathrm{X}$ \\
\hline & Anguilla anguilla & & $\mathrm{X}$ & $\mathrm{X}$ & $\mathrm{X}$ \\
\hline & Alosa fallax & & & $\mathrm{X}$ & $\mathrm{X}$ \\
\hline & Salmo trutta trutta & $\mathrm{X}$ & $\mathrm{X}$ & $\mathrm{X}$ & \\
\hline $\mathbf{E}$ & Salmo trutta marmoratus & $\mathrm{X}$ & $\mathrm{X}$ & $\mathrm{X}$ & \\
\hline * & Oncorhynchus mykiss & $\mathrm{X}$ & $\mathrm{X}$ & & \\
\hline \multirow[t]{3}{*}{ * } & Salvelinus fontinalis & $\mathrm{X}$ & & & \\
\hline & Thymallus thymallus & & $\mathrm{X}$ & $\mathrm{X}$ & \\
\hline & Esox lucius & & & $\mathrm{X}$ & $X$ \\
\hline \multirow[t]{2}{*}{$\mathbf{E}$} & Rutilus aula & & & $\mathrm{X}$ & $\mathrm{X}$ \\
\hline & Leusciscus cephalus & & $\mathrm{X}$ & $\mathrm{X}$ & \\
\hline \multirow[t]{6}{*}{$\mathbf{R}$} & Leusiscus souffia & & $\mathrm{X}$ & & \\
\hline & Phoxinus phoxinus & $\mathrm{X}$ & $\mathrm{X}$ & $\mathrm{X}$ & $X$ \\
\hline & Tinca tinca & & $\mathrm{X}$ & $X$ & \\
\hline & Scardinius erythrophthalmus & & $\mathrm{X}$ & $\mathrm{X}$ & \\
\hline & Alburnus alburnus alborella & & $\mathrm{X}$ & $X$ & \\
\hline & Chondrostoma toxostoma & & $\mathrm{X}$ & $X$ & \\
\hline \multirow[t]{2}{*}{$\mathbf{R}$} & Gobio gobio & & $\mathrm{X}$ & & \\
\hline & Barbus barbus plebejus & & $\mathrm{X}$ & $\mathrm{X}$ & $X$ \\
\hline$*$ & Cyprinus carpio & & & $\mathrm{X}$ & \\
\hline * & Carassius carassius & & $\mathrm{X}$ & & \\
\hline \multirow[t]{4}{*}{ * } & Carassius auratus & & $\mathrm{X}$ & & \\
\hline & Cobitis taenia & & $\mathrm{X}$ & $\mathrm{X}$ & \\
\hline & Gasterosteus aculeatus & & $\mathrm{X}$ & $\mathrm{X}$ & $\mathrm{X}$ \\
\hline & Cottus gobio & $X$ & $X$ & $\mathrm{X}$ & \\
\hline \multirow[t]{2}{*}{ * } & Lepomis gibbosus & & $X$ & $\mathrm{X}$ & $X$ \\
\hline & Perca fluviatilis & & $\mathrm{X}$ & & \\
\hline $\mathbf{E}$ & Padogobius martensi & & & $\mathrm{X}$ & \\
\hline \multirow[t]{2}{*}{$\mathbf{E}$} & Orsinigobius punctatissimus & & & $\mathrm{X}$ & \\
\hline & Number of Species & 6 & 23 & 23 & 10 \\
\hline
\end{tabular}

by occasional massive erosion, and re-established by rapid regeneration by willows and poplars. Localized sedimentation and subsequent island formation are undoubtedly facilitated once woody vegetation becomes established. Island development and succession of the vegetation are tightly connected (Edwards et al., 1999). Early-successional stages are linked in a cyclic process by the flood regime, by positive interactions between growth of woody species and sedimentation, and increasing stability of more established islands. Under these conditions island development in streams seems to be a unique form of cyclic succession (sensu Glenn-Lewin and van der Maarel, 1992) that does not fit within the standard concepts of succession and zonation within Alpine flood plains (Moor, 1958; Heller, 1969; Ellenberg, 1988). Clearly, in the active zone of an Alpine floodplain river, succession never reaches the stage of mature softwood or hardwood forests that are typical for less frequently disturbed or higher elevation sites on flood plains (Hupp and Osterkamp, 1985; Schnitzler, 1997).
The dynamic nature of a section of the Tagliamento River corridor was investigated by analysing aerial photographs of a 125 ha active floodplain zone for three different dates (1984, 1986, 1991). Dramatic changes in landscape configuration were documented, although the relative proportion of pioneer islands, established islands and river channels remained relatively constant (Vieli, 1998; Kollmann et al., 1999). Other studies have shown that the total area of woody vegetation in a braided river can change considerably over time, e.g. Bayard and Schweingruber (1991) for the Maggia, Switzerland (1933-1987) or Marston et al. (1995) for the Ain River France (1945-1991). Photographs from the Tagliamento in 1917 and 1945 show a much lower cover of woody vegetation than in recent years, perhaps reflecting a longterm trend caused by anthropogenic impacts (decrease of the water table, increased nutrient load, or changes in the input of LWD) (also see Astori, 1993). 


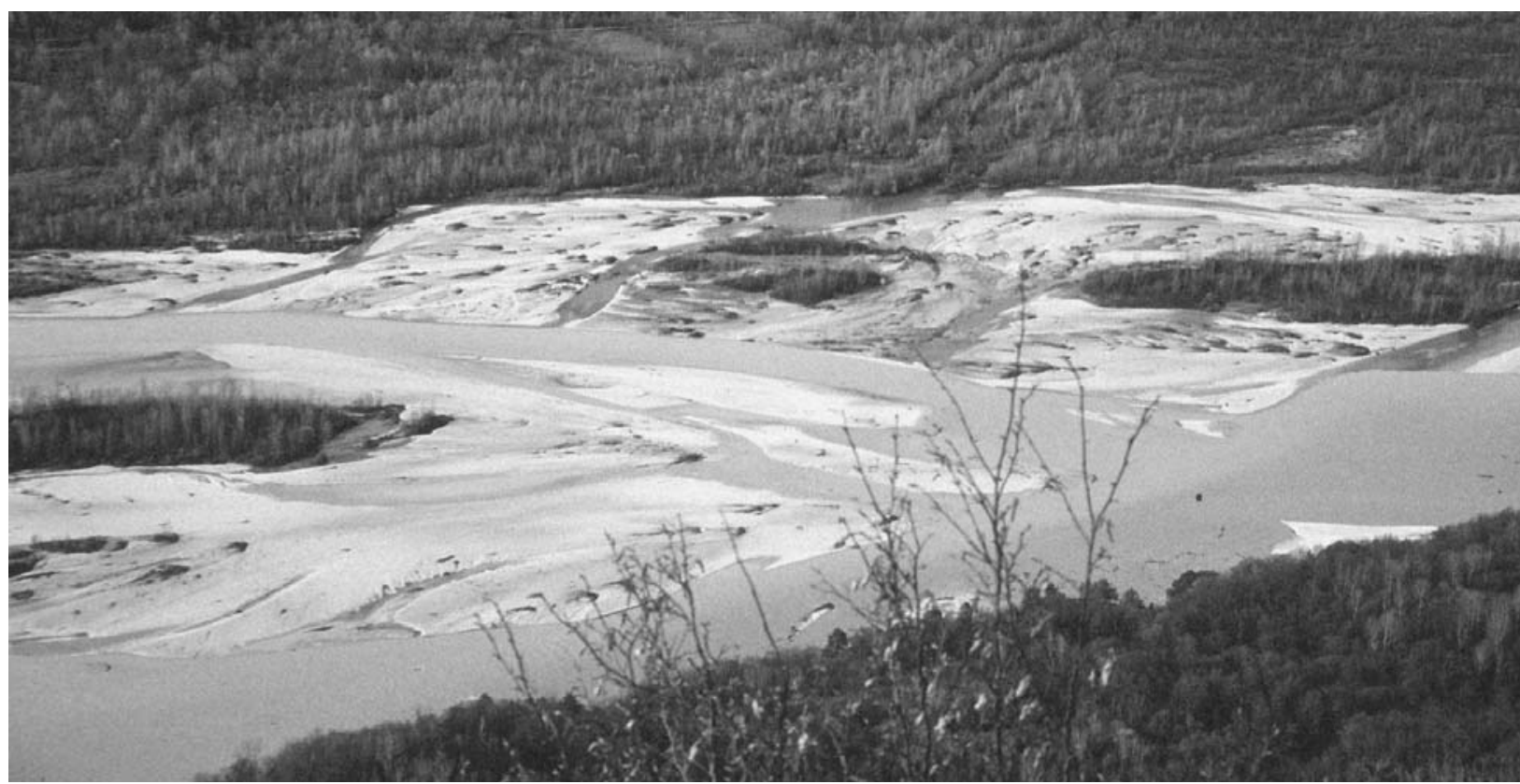

Figure 8. Oblique aerial view of the island-braided section upstream of Pinzano illustrating the high habitat diversity. Note the clear backwater in contrast to the turbid floodwaters of the main channel (Photo: K. Tockner; 1997).

\section{Island distribution}

There probably are 652 established river islands $\left(>70 \mathrm{~m}^{2}\right)$ along the river corridor of the Tagliamento (Ward et al., 2000 ). The maximum number of islands per river- $\mathrm{km}$ was 25 (Fig. 9A) with up to 400 islands per $\mathrm{km}^{2}$ of active flood plain. The combined surface area of all islands $\left(10.6 \mathrm{~km}^{2}\right)$ corresponded to $17 \%$ of the total area of the active corridor. These islands contributed considerably to the total ecotone length (riparian forest boundary zone); about $50 \%$ of the total ecotone length $(668 \mathrm{~km})$ can be attributed to the presence of islands (Ward et al., 2000). Surface area of individual islands ranged from 0.007 ha to 41.7 ha. Most islands were small in headwater sections compared to islands in the middle and the lower sections. In all sections, however, size heterogeneity of islands was high (Fig. 9B). The diversity and complexity of island patterns suggest that different processes are involved in their formation. A typology of islands based on formation process, size, form and structure is clearly needed (Gurnell et al., 2001).

In addition to the 652 established islands, countless pioneer islands (Phase I and Phase II islands, sensu Edwards et al., 1999) were observed along the river corridor. Gurnell et al. (2001) stress that pioneer islands, despite their limited areal extend, are important in retaining large woody debris (LWD). They calculated an average storage of 293 to 1664 tonnes $\mathrm{ha}^{-1} \mathrm{LWD}$ on pioneer islands compared to 1-6 tonnes $\mathrm{ha}^{-1}$ on exposed bare gravel surfaces.

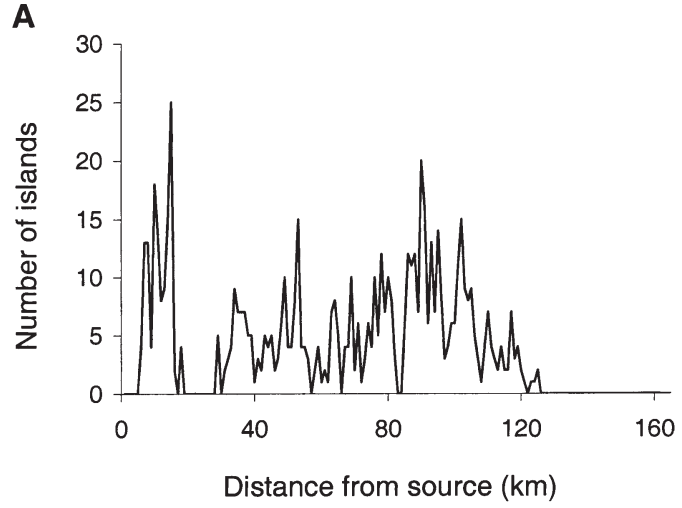

\section{B}

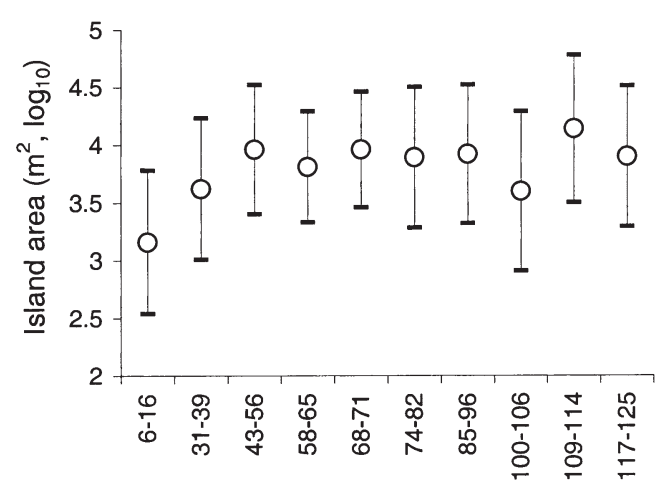

River segment (km)

Figure 9. A: Islands per river-km along the river corridor (based on the analysis of information derived from air-photographs and 1:10000 scale maps; 1984-1985). B: Size distribution of islands in different sections along the corridor (average $\pm \mathrm{SD}$ ). 


\section{Ecological importance of islands}

Most of what we know about bars and islands relates mainly to formation dynamics from the perspectives of hydraulics and fluvial geomorphologists (Fetherston et al., 1995; Abbe and Montgomery, 1996; Osterkamp, 1998). However, the ecological role of islands has been largely ignored by stream ecologists (Ward et al., 2000) because so few remain, even in the least impacted river systems. Islands are one of the first features to be eliminated from river systems by human alterations for flood control and navigation.

The presence and dynamics of vegetated islands likely have an important influence on biodiversity by providing a variety of aquatic and terrestrial habitats (Fig. 10). Islands and bars are frequently associated with backwaters, which together with eddies and floodplain lakes may provide important refuge areas for invertebrates and fish. For example, a high proportion of juvenile fish occur in floodplain ponds and backwaters (K. Tockner, pers. observation), in particular if these habitats contain LWD. In addition, ponds and backwaters produce large amounts of algal biomass that may drive metabolism in high order reaches (Thorp and Delong, 1994). "Dead zones" like backwaters are not only important centres for "instream productivity" but also increase the overall retentiveness of rivers.

Riverine dynamics also create a diversity of floodplain habitats for terrestrial invertebrates. The relative proportion of four major terrestrial groups, Formicidae, Arachnidae, Carabidae and Staphylinidae changed markedly across a riparian-floodplain transect (Fig. $10 \mathrm{~A}$ ). Carabidae and Staphylinidae beetles are able to rapidly colonise unstable habitats such as gravel bars and shorelines due to their high dispersal capacity. In the more stable riparian habitats, ants and spiders predominate. Based on the community structure of the carabid fauna, Rust (1998) identified three major habitat groups: (1) riparian forest and established islands (2) LWD and pioneer islands, and (3) bare gravel bars and shoreline habitats. In a random sample of 100 individuals, the expected number of carabid species was 27 for group 1 habitats, 24 for group 2, and 13 for group 3 (Fig. $10 \mathrm{~B})$. Established and pioneer islands were characterised by a high proportion of rare species; however, highest abundance was found along shorelines (up to 150 Ind. $\mathrm{m}^{-2}$ ). This undoubtedly is attributed to concentration of prey species, i.e., emerging insects and drifting invertebrates, at shoreline locations (Hering and Plachter, 1997).

Thirteen Amphibian taxa were identified along the Tagliamento with Rana latastei and Bufo bufo being predominate (Klaus et al., 2001). In the main study reach, a $2 \mathrm{~km}^{2}$ dynamic island-braided flood plain in the middle section of the river, 130 waterbodies were delineated that were situated either in the active flood plain
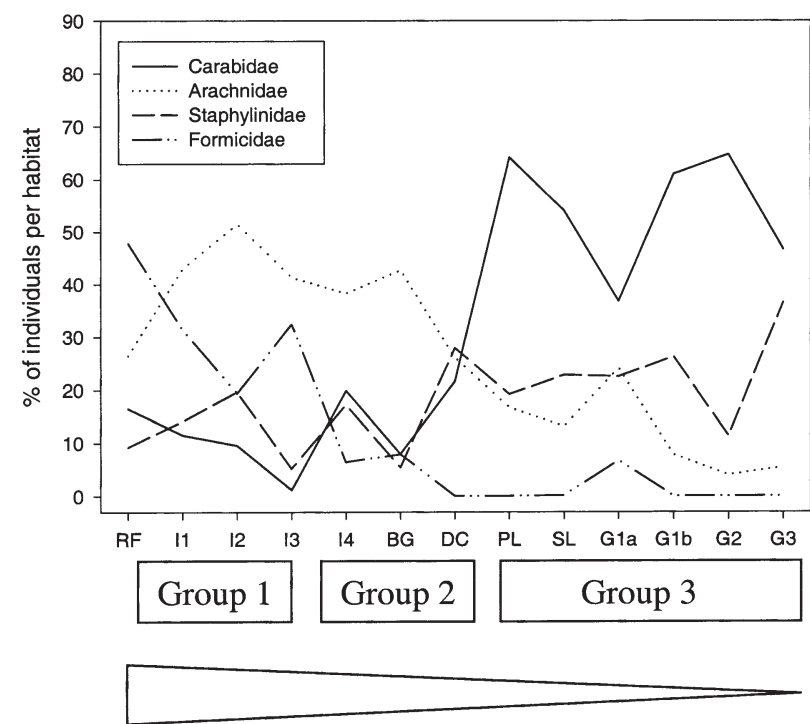

A

Riparian Forest

Gravel Bar

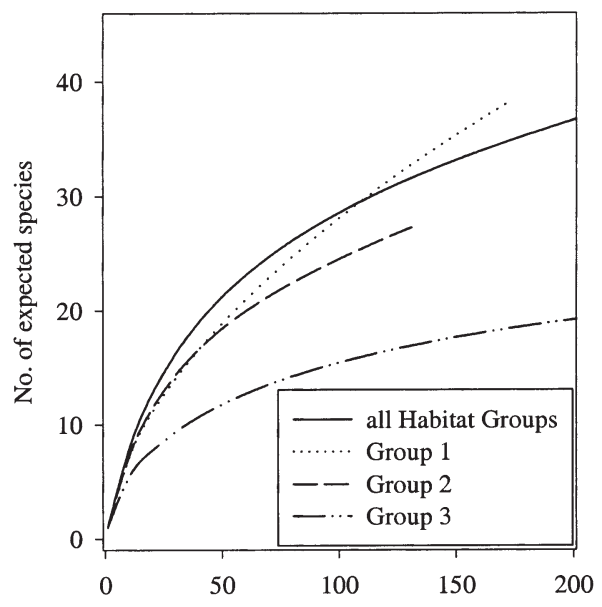

B

No. of individuals

Figure 10. A. Relative proportion (\%) of four terrestrial invertebrate taxa across a floodplain transect (upstream of Pinzano, Fig. 8). B: Carabid beetles: Species/abundance relationship (rarefaction curves) in three distinct habitat types and in all habitat types combined (see text) (Rust, 1998). RF: Riparian forest; $\mathrm{I}_{1}-\mathrm{I}_{3}$ : Established islands; BG: Bare gravel; DC: Dry channel; PL\&SL: Shoreline habitats; $\mathrm{G}_{1-}{ }_{3}$ : Gravel bar shoreline.

(82 sites) or in the adjacent riparian forest (48 sites). Results demonstrated that the active flood plain increased appreciably the available habitat for amphibians, despite frequent disturbances by floods or droughts. Amphibian richness within a given habitat was significantly related to distance from islands, fish density and water temperature. Vegetated islands and large woody debris played pivotal roles, directly and indirectly, in maintaining both habitat and amphibian diversity in this gravel-bed river. 


\section{Perspectives}

Conservation and restoration goals should be compatible with fundamental ecological theory (Stanford et al., 1996; Tockner et al., 1998; Ward et al., 2001; Tockner and Stanford, 2002). The fundamental concepts that underpin current scientific knowledge of riverine ecosystems have been formulated over the past two decades. In their initial formulations, both the River Continuum Concept (Vannote et al., 1980) and the Serial Discontinuity Concept (Ward and Stanford, 1983) ignored floodplain dynamics, although subsequent modifications rectified this to some extent (Sedell et al., 1989; Ward and Stanford, 1995). The Flood Pulse Concept (Junk et al., 1989; Tockner et al., 2001), although focusing on floodplain dynamics, is based largely on tropical rivers. What is lacking is a rigorous conceptual model for dynamic floodplain rivers of the temperate zone. The limited empirical knowledge of dynamic processes operating in natural systems means that we lack sound »benchmarks « not only for assessing human impacts, but also for addressing restoration and conservation strategies.

The Tagliamento River in Italy offers the rare opportunity to investigate natural processes at a scale that can be studied nowhere else in Europe. This remarkable river corridor exemplifies the ecological processes and patterns that must have characterised Alpine gravel bed rivers. The Fiume Tagliamento is clearly a river ecosystem of European importance, since it constitutes a unique resource as a model reference catchment. Therefore, the present authors have initiated a major research programme which integrates hydrology, geomorphology and ecology of the Tagliamento River corridor (Edwards et al., 1999; Gurnell et al., 2000a, b, 2001; Kollmann et al., 1999; Tockner and Ward, 1999; Arscott et al., 2000, 2001; Ward et al., 1999b, 2000). The outcome of the research programme is intended not only to advance knowledge of natural rivers, but will also provide the scientific basis for more sustainable management of functional processes. We wish to establish a hierarchical landscape perspective for riparian ecosystems as an essential basis for developing catchment-wide restoration and conservation strategies that include (i) preservation of unconstrained riparian corridors, (ii) maintenance of flow variability, and (iii) preservation of the capacity of the system to undergo change. It is already clear that the factors controlling ecosystem processes or biodiversity patterns operate across a range of spatio-temporal scales that transcend traditional river management programmes.

Specifically, three major aspects are deemed essential for understanding Alpine braided gravel bed rivers: (i) viewing river-floodplain ecosystems as hierarchical ecosystems containing nested spatial and temporal scales, (ii) linking terrestrial and aquatic ecosystems, (iii) investigating the actual processes of island dynamics.
River-floodplain ecosystems are expanding, contracting, and often fragmented ecosystems (Stanley et al., 1997; Ward et al., 1999c; Malard et al., 1999; Tockner et al., 2000). These changes in size are thought to control habitat availability and environmental conditions as well as faunal/floral composition and ecological processes. The expansion and contraction cycle is a fundamental property of all floodplain ecosystems, although, it has been generally neglected by stream ecologists. We propose that the Flood Pulse Concept could be adapted to accommodate the characteristics of river-floodplain systems outside tropical climates, particularly those in the temperate zone. Furthermore, water level fluctuations well below 'bankfull' may dominate ecosystem processes and the distribution of biotic communities ('flow pulse' vs. 'flood pulse'; Puckridge et al., 1998; Tockner et al., 2000). The present authors are particularly interested in the dynamics of vegetated islands on the active flood plain and their role in maintaining biodiversity (Ward et al., 1999b). The fact that anthropogenic impacts have eliminated islands from many rivers makes an understanding of their role even more crucial. Islands not only provide information of recent geomorphic history and processes but island dynamics may also serve as an ecosystem-level indicator of the condition of riverine corridors (Ward et al., 2000, 2001).

However, the Tagliamento is a highly endangered ecosystem. The regional government is planning $14 \mathrm{~km}^{2}$ large flood retention basins in the most natural section. About $30 \mathrm{mill} \mathrm{m}^{3}$ of material, mainly gravel, will be excavated. These retention basins should protect urban areas along the channelized downstream section of the river against floods of up to $100-\mathrm{yr}$ events. In addition, a highway following the main stem of the river and new industrial areas will severely impact the corridor. The future conservation of the Tagliamento will be a benchmark for the European Water Framework Directive (WFD). If we are not able to protect the last semi-natural rivers, the discussions on restoration projects remain useless. Therefore, scientists are working closely together with conservation agencies in order to develop a sustainable management plan for the Tagliamento River, which is called the "King of the Alpine Rivers".

\section{Acknowledgments}

We thank Achim Paetzold, Luana Bottinelli, Peter Burgherr, Urs Holliger, Richard Illi, Ute Karaus, and Christian Rust (EAWAG/Dübendorf), Fabio Stoch (Trieste), Antonella Astori (Tolmezzo), Roberto Furlan and Alberto Deano (Trieste), Francesco Baruffi and Nicola Surian (Venice), Bruna Gumiero (Bologna), Nicoletta Toniutti (WWF), Andrea Marin (Udine), and Mario Vieli (Geobotanical Institute, ETH) for their valuable contribu- 
tions. Supported in part by a research grant from the ETH-Zürich and by Grant GR9/03249 from the UK NERC to AMG and GEP.

\section{References}

Abbe, T. B. and D. R. Montgomery, 1996. Large woody debris jams, channel hydraulics and habitat formation in large rivers. Reg. Riv. 12: 201-221.

Arscott, D. B., K. Tockner and J. V. Ward, 2000. Aquatic habitat diversity along the corridor of an Alpine floodplain river (Fiume Tagliamento, Italy). Archiv Hydrobiol. 149: 679-704.

Arscott, D. B., K. Tockner and J. V. Ward, 2001. Thermal heterogeneity along a braided floodplain river (Tagliamento River, northeastern Italy). Can. J. Fish. Aquat. Sci. 58: 2359-2373.

Arscott, D. B., K. Tockner, D. Van der Nat and J. V. Ward, 2002. Aquatic habitat dynamics along a braided Alpine river ecosystem (Tagliamento River, Northeast Italy). Ecosystems 5: 802-814

Astori, A., 1993. Morfologie alluvionali e dinamica fluviale di un fiume-torrente Alpino: il F.Tagliamento a Tolmezzo (Carnia), Master Thesis, Univ. of Padova.

Baumgartner, A., E. Reichel and G. Weber, 1983. Der Wasserhaushalt der Alpen, R. Oldenburg, Munich.

Bayard, M. and F. H. Schweingruber, 1991. Ein Baumgrenzstandort: Das Wildwasserbett der Maggia im Tessin, Schweiz. Eine dendroökologische Studie. Bot. Helv. 101: 9-28.

Benke, A. C., I. Chaubey, M. G. Ward and E. L. Dunn, 2000. Flood pulse dynamics of an unregulated river floodplain in the southeastern U.S. coastal plain. Ecology 81: 2730-2741.

Bill, H.-Ch., P. Poschlod, M. Reich and H. Plachter, 1999. Experiments and observations on seed dispersal by running water in an Alpine floodplain. Bull. Geobot. Inst. ETH 65: 13-28.

Billi, P., R. D. Hey, C. R. Thorne and P. Tacconi, 1992. Dynamics of gravel-bed rivers, Wiley, Chichester.

Bormann, F. H. and G. E. Likens, 1979. Pattern and process in a forested ecosystem, Springer, New York.

Cattaneo, A., G. Salmoiraghi and S. Gazzera, 1995. The rivers of Italy. In: C. E. Cushing, K. W. Cummins and G. W. Minshall (eds.), River and stream ecosystems. Elsevier, Amsterdam, pp. 479-505.

CIPRA, 1998. Alpenreport, Verlag Haupt, Bern.

Dynesius. M. and C. Nilsson, 1994. Fragmentation and flow regulation in the northern third of the world. Science 266: 753-762.

Edwards, P. J., J. Kollmann, A. M. Gurnell, G. E. Petts, K. Tockner and J. V. Ward, 1999. A conceptual model of vegetation dynamics on gravel bars of a large Alpine river. Wetlands Ecol. Manag. 7: 141-153.

Electroconsult, 1979. Tagliamento: Dati idrologici. Rapporto preliminare, Regione Autonoma Friuli-Venezia Giulia, Trieste.

Ellenberg, H., 1988. Vegetation ecology of central Europe, Cambridge University Press, Cambridge.

Fetherston, K. L., R. J. Naiman and R. E. Bilby, 1995. Large woody debris, physical process, and riparian forest development in montane river networks of the Pacific Northwest. Geomorphology 13: 133-144.

Gentilli, J., 1971. Il Friuli, I Climi. Udine.

Gerken, B., K. Dörfer, M. Buschmann, S. Kamps-Schwob, J. Berthelmann and D. Gertenbach, 1991. Composition and distribution of carabid communities along rivers and ponds in the region of the Upper Weser (NW/ND/FRG) with respect to protection and management of a floodplain ecosystem. Reg. Riv. 6: 313-320

Glenn-Lewin, D. C. and E. van der Maarel, 1992. Patterns and processes of vegetation dynamics. In: D. C. Glenn-Lewin, R. K. Peet and T. T. Veblen (eds.), Plant succession: theory and prediction, Chapman and Hall, London, pp. 11-59.
Gurnell, A. M. and G. E. Petts, 2002. Island-dominated landscapes of large floodplain rivers, a European perspective. Freshwat. Biol. 47: 581-600.

Gurnell, A. M., G. E. Petts, D. M. Hannah, B. P. G. Smith, P. J. Edwards, J. Kollmann, J. V. Ward and K. Tockner, 2000a. Wood storage within the active zone of a large European gravel-bed river. Geomorphology 34: 55-72.

Gurnell, A. M., G. M. Petts, N. Harris, J. V. Ward, K. Tockner, P. J. Edwards and J. Kollmann, 2000b. Large wood retention in river channels: The case of the Fiume Tagliamento, Italy. Earth Surf. Proc. Land. 25: 255-275.

Gurnell, A. M., G. E. Petts, D. M. Hannah, B. P. G. Smith, P. J. Edwards, J. Kollmann, J. V. Ward and K. Tockner, 2001. Island formation along the gravel-bed Fiume Tagliamento, Italy. Earth Surf. Proc. Land. 26: 31-62.

Heidt, E., V. Framenau, D. Hering and R. Manderbach, 1998. Die Spinnen- und Laufkäferfauna auf ufernahen Schotterbänken von Rhone, Ain (Frankreich) und Tagliamento (Italien) (Arachnida: Araneae; Coleoptera: Carabidae). Entomol. Z. 108: $142-153$.

Heller, H., 1969. Lebensbedingungen und Abfolge der Flussvegetation in der Schweiz. Mit. Schweiz. Anstalt forstl. Versuchswesen 45: $1-124$.

Hering, D. and H. Plachter, 1997. Riparian ground beetles (Coleoptera, Carabidae) preying on aquatic invertebrates: a feeding strategy in alpine floodplains. Oecologia 111: 261-270.

Hormann, K., 1964. Torrenten in Friaul und die Längsprofilentwicklung auf Schottern, Münchner geographische Hefte, Heft 29, München.

Hupp, C. R. and W. R. Osterkamp, 1985. Bottomland vegetation distribution along passage creek, Virginia, in relation to fluvial landforms. Ecology 66: 670-681.

Junk W. J., P. B. Bayley and R. E. Sparks, 1989. The flood pulse concept in river-floodplain systems. Can. Spec. Publ. Fish. Aquat. Sci. 106: 110-127.

Klaus, I., C. Baumgartner and K. Tockner, 2001. Die Wildflusslandschaft des Tagliamento (Italien, Friaul) als Lebensraum für eine artenreiche Amphibiengesellschaft. Z. f. Feldherpet. 8: 21-30.

Kollmann, J., M. Vieli, P. J. Edwards, K. Tockner and J. V. Ward, 1999. Interactions between vegetation development and island formation in the Alpine river Tagliamento. Appl. Veg. Sci. 2: 25-36.

Lippert, W., N. Müller, S. Rossel, T. Schauer and G. Vetter, 1995. Der Tagliamento - Flussmorpholgie und Auenvegetation der grössten Wildflusslandschaft der Alpen. J. Ver. z. Sch. Bergw. 60: $11-70$.

Lohmeyer, W. and H. Sukopp, 1992. Agriophyten in der Vegetation Mitteleuropas. Schrift. Vegetationskunde 25: 1-185.

Malard, F., K. Tockner and J. V. Ward, 1999. Shifting dominance of subcatchment water sources and flow paths in a glacial floodplain, Val Roseg, Switzerland. Arct. Ant. Alp. Res. 31: $135-150$.

Malanson, G. P., 1993. Riparian landscapes, Cambridge University Press, Cambridge.

Maione, U. and G. Machne, 1982. Studio sulla formazione delle piene del Fiume Tagliamento, ECOCONSULT, Milano.

Marston, R. A., J. Girel, G. Pautou, H. Piégay, J.-P. Bravard and C. Arneson, 1995, Channel metamorphosis, floodplain disturbance, and vegetation development: Ain River, France. Geomorphology 13: 121-131.

Martinet, F. and M. Dubost, 1992. Die letzten naturnahen Alpenflüsse-Versuch eines Inventars, CIPRA, Vaduz, FL.

Martinis, B., 1993. Storia geologica del Friul, La Nuova Base Ed., Udine.

Meybeck, M., 1996. River water quality: Global ranges, time and space variabilities, proposal for some redefinitions. Verh. Internat. Verein. Limnol. 26: 81-96. 
Moor, M., 1958. Die Pflanzengesellschaften schweizerischer Flussauen. Mitt. Schweiz. Anst. forstl. Versuchsw. 34: 221-360.

Mosetti, F., 1983. Sinisti sull'idrologica del Friuli-Venzia Giulia, Quaderni dell'Ente Tutela Pesce del Friuli-Venzia Giulia, Rivista di Limnologia, No 6.

Muhar, S., M. Kainz, M. Kaufmann and M. Schwarz, 1998. Erhebung und Bilanzierung flusstypspezifisch erhaltener Fliessgewässerabschnitte in Österreich. Öst. Wasser Abfallwirtschaft 5/6: 119-127.

Müller, N., 1995. River dynamics and floodplain vegetation and their alterations due to human impact. Arch. Hydrobiol. Suppl. 101: 477-512.

Osterkamp, W. R., 1998. Processes of fluvial island formation, with examples from Plum Creek, Colorado and Snake River, Idaho. Wetlands 17: 530-545.

Petts, G. E., H. Möller and A. L. Roux, 1989. Historical change of large alluvial rivers: Western Europe, Wiley, Chichester.

Plachter, H., 1998. Die Auen alpiner Wildflüsse als Modelle störungsgeprägter ökologischer Systeme. Schf.-R.f. Landschaftspfl. u. Naturschutz 56: 21-66

Poldini, L., 1991. Atlante corologico delle piante vascolari nel Friuli-Venzia Giulia, Università degli Studi di Trieste, Trieste.

Provincia di Udine, 1997. Mappaggio biologico di qualità dei corsi d'acqua della provincia di Uine, Udine, 104pp.

Puckridge, J. T., F. Sheldon, K. F. Walker and A. J. Boulton, 1998. Flow variability and the ecology of large rivers. Mar. Freshw. Res. 49: 55-72.

Regione Autonoma Friuli-Venezia Giulia, 1982. Mappatura automatica delle risorse idriche regionali, Trieste.

Reich, M., 1994. Kies- und schotterreiche Wildflusslandschaften primäre Lebensräume des Flussregenpfeifers (Charadrius dubius). Vogel u. Umwelt 8: 43-52.

Rust, C., 1998. Die ökologische Bedeutung von Inseln und Schotterbänken im Tagliamento (Friaul, Italien) am Beispiel der Laufkäferzönose (Carabidae, Insecta), Diplomarbeit, ETHZürich.

Schnitzler, A., 1997. River dynamics as a forest process: Interaction between fluvial systems and alluvial forests in large European river plains. The Bot. Rev. 63: 40-64.

Sedell, J. R., J. E. Richey and F. J. Swanson, 1989. The river continuum concept: a basis for the expected ecosystem behavior of very large rivers? Can. Spec. Publ. Fish. Aquat. Sci. 106: 49-55.

Stanley, E. H., S. G. Fisher and N. B. Grimm, 1997. Ecosystem expansion and contraction in streams. BioScience 47: 427435.

Stanford, J. A., J. V. Ward, W. J. Liss, C. A. Frissell, R. N. Williams, J. A. Lichatowitch, and C. C. Coutant, 1996. A general protocol for restoration of regulated rivers. Reg. Riv. 12: 391-413.

Stefanini, S., 1982. Le sistemazioni idraulico-forestali nella Carnia (bacino montana del Fiume Tagliamento), Regione Autonoma Friuli-Venezia Giulia, Trieste.

Steinicke, E., 1991. Friaul. Bevölkerung und Ethnizität, Innsbrucker Geogr. Studien 19. Inst. für Geographie, Univ. Innsbruck.

Stoch, F., S. Paradisi and M. B. Dancevich, 1992. Carta Ittica del Friuli-Venezia Giulia, ETP, Udine.
Thorp, I. H. and M. D. Delong, 1994. The riverine productivity model: an heuristic view of carbon sources and organic processing in large river ecosystems. Oikos 70: 305-308.

Tockner, K., F. Schiemer and J. V. Ward, 1998. Conservation by restoration: the management concept for a river-floodplain system on the Danube River in Austria. Aquat. Conserv. 8: 71-86.

Tockner, K. and J. V. Ward, 1999. Biodiversity along riparian corridors. Arch. Hydrobiol. Suppl. 115: 293-310.

Tockner, K., F. Malard and J. V. Ward, 2000. An extension of the Flood Pulse Concept. Hydrol. Proc. 14: 2861-2883.

Tockner, K. and J. A. Stanford, 2002. Riverine flood plains: present state and future trends. Envir. Conserv. 29: 308-330.

Tutin, T. G., V. H. Heywood, N. A. Burges, D. H. Valentine, S. M. Walters and D. A. Webb, 1964-80. Flora Europaea, Vol. 1-5, Cambridge University Press, Cambridge.

Van der Nat, D., A. P. Schmid, K. Tockner, P. J. Edwards and J. V. Ward, 2002. Inundation dynamics in braided floodplains: Tagliamento River, northeast Italy. Ecosystems 5: 636-647.

Vannote, R. L., G. W. Minshall, K. W. Cummins, J. R. Sedell and C. E. Cushing, 1980. The river continuum concept. Can. J. Fish. Aquat. Sci. 37: 130-137.

Vieli, M., 1998. Luftbild- und GIS-gestützte Vegetationsuntersuchungen am Tagliamento, Diplomarbeit, Univ. Zürich und ETH-Zürich.

Ward, J. V., 1985. Thermal characteristics of running waters. Hydrobiol. 125: 31-46.

Ward, J. V., 1998. Riverine landscapes: biodiversity patterns, disturbance regimes, and aquatic conservation. Biol. Cons. 83: 269-278.

Ward, J. V. and J. A. Stanford, 1983. The serial discontinuity concept of lotic ecosystems. In: T. D. Fontaine and S. M. Bartell (eds.), Dynamics of lotic ecosystems, Ann Arbor Science, Ann Arbor, MI, pp. 29-42.

Ward, J. V. and J. A. Stanford, 1995. The serial discontinuity concept: extending the model to floodplain rivers. Reg. Riv. 10: 159-168.

Ward, J. V. and K. Tockner, 2001. Biodiversity: towards a unifying theme for river ecology. Freshwat. Biol. 46: 807-819.

Ward, J. V., K. Tockner and F. Schiemer, 1999a. Biodiversity of flooplain river ecosystems: ecotones and connectivity. Reg. Riv. 15: 125-139.

Ward, J. V., K. Tockner, P. J. Edwards, J. Kollmann, G. Bretschko, A. M. Gurnell, G. E. Petts and B. Rossaro, 1999 b. A reference system for the Alps: the 'Fiume Tagliamento'. Reg. Riv. 15: 63-75.

Ward, J. V., F. Malard, K. Tockner and U. Uehlinger, 1999c. Influence of ground water on surface water conditions in a glacial flood plain of the Swiss Alps. Hydrol. Proc. 13: 277-293.

Ward, J. V., K. Tockner, P. J. Edwards, J. Kollmann, G. Bretschko, A. M. Gurnell, G. E. Petts and B. Rossaro, 2000. Potential role of island dynamics in river ecosystems. Verh. Int. Verein. Limnol. 27: 2582-2585.

Ward, J. V., K. Tockner, U. Uehlinger and F. Malard, 2001. Understanding natural patterns and processes in river corridors as the basis for effective river restoration. Reg. Riv. 17: 311-323.

Wintersberger, H., 1996. Spatial resource utilisation and species assemblages of larval and juvenile fish. Arch. Hydrobiol. Suppl. 115: $29-44$ 